Sharpe, M. Elisabeth (1952). J. gen. Microbiol. 7, 192-199

\title{
Occurrence of a Common Type Antigen in Streptococci of Groups D and N
}

\author{
By M. ELISABETH SHARPE \\ The National Institute for Research in Dairying, University of Reading
}

SUMMARY: A streptococcus reacting with both group $\mathrm{D}$ and group $\mathrm{N}$ specific antisera was found to belong to group $\mathbf{D}$; the reaction with the group $\mathbf{N}$ serum was shown by reciprocal absorption tests to be due to a common type antigen. Two group D strains were encountered having this antigen; both were identified as Streptococcus faecium. The group N strain possessing this same antigen was Streptococcus lactis. It proved to have at least one other type antigen, also found in another strain of Strep. lactis which was not serologically identical. Two antigenic variants were present in cultures of this organism; one possessed all the type antigens characterizing this strain the other had only one. Attempts to cause further dissociation or reversion were not successful.

Streptococci of different Lancefield groups having common type antigens have been previously reported; Bliss (1937) found a group F type to be serologically identical with a group $G$ type, and Maxted (1949) described four strains of streptococci, one belonging to group $\mathrm{B}$, two to group $\mathrm{C}$ and one to group $\mathbf{G}$, each having the $\mathbf{M}$ antigen of group $\mathbf{A}$, type 28 . When a streptococcus was encountered which reacted with both a group $\mathrm{D}$ and a group $\mathbf{N}$ specific antiserum in the precipitin test, using formamide extracts, it scemed likely that one of the reactions might have been due to a common type antigen. This was found to be so, and the following account is given of a group $\mathrm{D}$ and a group $\mathbf{N}$ streptococcus having a similar type antigen. Later another group D strain was found with this same antigen.

\section{MATERIALS AND METHODS}

The streptococcus strain 748, an extract of which reacted with a group D and a group $\mathbf{N}$ serum, was sent to this laboratory by Prof. M. Seelemann, Institut für Milchhygiene, Kiel. It was isolated from the blood of a case of endocarditis. Prof. Seelemann was also kind enough to send samples of his group $\mathrm{D}$ and group $\mathbf{N}$ sera, and the strains group D 753 (Seelemann \& Carstens, 1951 $a$ ) and group N 736 (Seelemann \& Carstens, 1951 b) from which they had been prepared.

Group D streptococcus 2766/1 was isolated from a Gruyère cheese from Cyprus by Dr B. C. Hobbs, Central Public Health Laboratory, Colindale, and sent to this laboratory for investigation.

\section{Cultural tests}

Growth at $45^{\circ}$; survival at $60^{\circ}$ for $30 \mathrm{~min}$. (Shattock, 1949).

Growth at $\mathrm{pH} 9 \cdot 6$ (Shattock \& Hirsch, 1947).

Growth at $40^{\circ}$; hydrolysis of arginine (Abd-el-Malek \& Gibson, 1948).

Resistance to 1:2500 potassium tellurite (Sharpe \& Shattock, 1952). 
Carbohydrate fermentation. Peptone water containing $0.5 \%(w / v)$ of the carbohydrate added after sterilization.

Strains 748 and $2766 / 1$ were incubated at $37^{\circ}$ and strain 736 at $30^{\circ}$ for all tests unless otherwise stated.

\section{Serological methods}

Preparation of antisera. Type sera. Formol-killed suspensions were inoculated into rabbits at twice weekly intervals for 3-4 weeks (Sharpe \& Shattock, 1952).

Group sera. Group D. The organisms were disrupted in a vibrating machine with carborundum (Shattock, 1949), and a course of four to six inoculations given at twice-weekly intervals. Group N. An $18 \mathrm{hr}$. culture grown in glucose ( $1 \%$ ) Lemco broth was centrifuged, washed in $\mathbf{0 . 8 5} \%(\mathrm{w} / \mathrm{v})$ saline and resuspended to its original volume in saline; it was then heated to $56^{\circ}$ for $1 \mathrm{hr}$. Twelve to fifteen inoculations were given at twice-weekly intervals using a freshly heat-killed suspension for each inoculation.

$\mathrm{HCl}$ extracts. Lancefield's (1933) method was used for preparing $\mathrm{HCl}$ extracts.

Formamide extracts. Fuller's (1938) method was used.

Precipitin ring tests. Extracts were layered over sera in tubes of $3 \mathrm{~mm}$. internal diameter and examined at intervals up to $30 \mathrm{~min}$.

Absorption tests. Using Shattock's (1949) technique, organisms were grown for $48 \mathrm{hr}$. in glucose Lemco broth and, after washing once in saline, the cells were resuspended in saline to give a density equivalent to 10 times Brown's opacity tube no. 10 (Burroughs Wellcome and Co. Ltd.). Suspensions of group D streptococci were killed by heating at $60^{\circ}$ for $1 \mathrm{hr}$. and the group $\mathrm{N}$ streptococci by heating at $56^{\circ}$ for $1 \mathrm{hr}$. The cells were then packed by centrifuging and suspended in undiluted serum so that the absorbing suspension had 50 times the opacity of Brown's tube no. 10. Sera were absorbed for $1 \mathrm{hr}$. at $37^{\circ}$ followed by overnight refrigeration. To ensure complete removal of antibodies, type sera were always reabsorbed with fresh organisms.

\section{RESULTS}

\section{Serological identification of strain $\mathbf{7 4 8}$}

$\mathrm{HCl}$ extracts of strain $\mathbf{7 4 8}$ gave precipitin reactions with two specific group D sera, Strep. durans $98 \mathrm{D}$ and Strep. bovis Pearl 11, but not with a specific group $\mathbf{N}$ serum Strep. lactis $\mathbf{O J}$. An antiserum was prepared against strain 748, using the method for preparing group D sera, and found to react specifically with $\mathrm{HCl}$ extracts of strains of known group D streptococci, all of different serological types, and also with an extract of strain 736. Group sera prepared against strains 753 and 736 reacted specifically with extracts of group $\mathbf{D}$ and group $\mathbf{N}$ streptococci respectively. In addition serum 736 reacted with an extract of strain 748 (Table 1). Using Seelemann's sera similar results were obtained. Reciprocal absorption tests with serum 748 and a group D serum prepared against Strep. durans $98 \mathrm{D}$ showed that 748 cells 
absorbed all the group antibodies from the group $\mathrm{D} 98 \mathrm{D}$ antiserum, and that the 748 antiserum contained group antibodies which were absorbed by the group D strain $98 \mathrm{D}$, but were not absorbed by the group $\mathbf{N}$ strain Strep. lactis $\mathrm{OJ}$ (Table 2). The streptococcus 748 is thus identified unequivocally as group D. This suggests that the precipitin reaction between 736 serum and an extract of strain 748 is due to a common type substance. The reaction between group D serum $\mathbf{7 5 3}$ and strain $\mathbf{7 4 8}$ is the normal group reaction.

Formamide extracts. Formamide extracts gave similar results to those recorded above, but the reactions were weaker. No further tests were made with extracts prepared in this way.

Table 1. Precipitin reactions of antisera prepared against streptococci strains 753, 748 and 736

\begin{tabular}{|c|c|c|c|}
\hline \multirow[b]{2}{*}{$\mathrm{HCl}$ extract prepared from strain } & \multicolumn{3}{|c|}{ Antiserum } \\
\hline & 753 & 748 & 736 \\
\hline Groups A-C, E-M & - & - & - \\
\hline \multicolumn{4}{|l|}{ Group D: } \\
\hline $\begin{array}{r}\text { Strep. faecalis S161 } \\
\text { N } 83\end{array}$ & $\begin{array}{l}+ \\
+\end{array}$ & $\begin{array}{l}+ \\
+\end{array}$ & - \\
\hline Strep. faecalis var. liquefaciens $\mathrm{N} 97$ & + & + & - \\
\hline Strep. faecalis var: zymogenes $\mathrm{N} 37$ & + & + & - \\
\hline Strep. bovis Pearl 11 & + & + & - \\
\hline Strep. durans 98D & + & + & - \\
\hline \multicolumn{4}{|l|}{ Group N: } \\
\hline Strep. lactis OJ & - & - & + \\
\hline M3 & - & - & $+t$ \\
\hline Rice & - & - & + \\
\hline Strep. cremoris HP & - & - & + \\
\hline RW & - & - & + \\
\hline $\mathbf{J}$ & - & - & + \\
\hline Strain 753 & + & + & - \\
\hline 748 & + & $+t+$ & ++ \\
\hline 736 & - & $++t$ & +++ \\
\hline
\end{tabular}

\section{Absorption of type specific antibodies from type antisera 748 and 736}

Using type sera from which all non-type specific antibodies had been absorbed by a heterologous strain of the same group, reciprocal absorption tests were carried out with sera prepared against strains 748 and 736 (Table 3). With serum 748 the precipitating type antibodies were completely absorbed by either 748 or 736 cells, leaving no reacting antibodies in the serum. With 736 serum, although the precipitating antibodies were completely removed by absorption with the homologous strain, absorption with 748 cells still left some reacting antibody, although the precipitin reaction was greatly reduced. It had been observed (Table 1) that the group $\mathrm{N}$ serum prepared against 736 gave a strong 
reaction with an extract of Strep. lactis M3, and it was thought that this might be due to another type antigen present, differing from that characterizing 748 as an extract of Strep. lactis M3 did not react with 748 type serum. Accordingly, absorption tests with this organism were also included (Table 3), and the presence of a second type antigen was confirmed; the group $\mathrm{N}$ streptococcus

Table 2. Reciprocal absorptions of group $D$ serum $98 D$ and serum 748, as shown by precipitin reactions

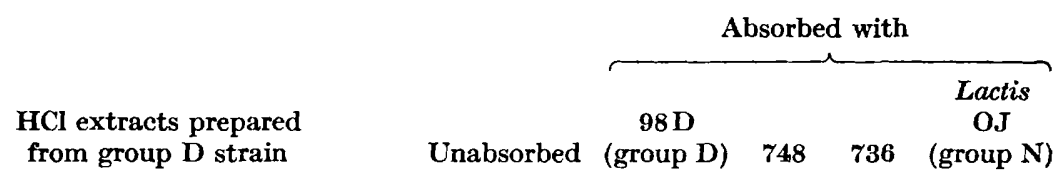

Absorption of group D serum 98 D

Strep. faecalis, 2 strains: $\mathrm{S} 161$ and $\mathrm{N} 83$

Strep. faecalis var. liquefaciens $\mathrm{N} 97$

Strep. faecalis var. zymogenes $\mathbf{N} 37$

Strep. bovis Pearl 11

Strep. durans $98 \mathrm{D}$

Strain 753

748

736

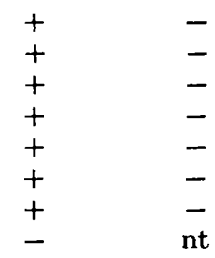

$\begin{array}{lll}- & - & + \\ - & - & + \\ - & - & + \\ - & - & + \\ - & + & + \\ - & - & + \\ \text { nt } & \text { nt } & \text { nt }\end{array}$

$\begin{array}{ll}+ & + \\ + & + \\ + & + \\ + & + \\ + & + \\ + & + \\ + & + \\ \text { nt } & \text { nt }\end{array}$

Absorption of serum $\mathbf{7 4 8}$

Strep. faecalis, 2 strains: S161 and N 83

Strep. faecalis var. liquefaciens N97

Strep. faecalis var. zymogenes N37

Strep. bovis Pearl 11

Strep. durans $98 \mathrm{D}$

Strain 753

748

736

$\begin{array}{ccccc}+ & - & - & + & + \\ + & - & - & + & + \\ + & - & - & + & + \\ + & - & - & + & + \\ + & - & - & + & + \\ + & - & - & + & + \\ +++ & +++ & - & + & +++ \\ +++ & +++ & - & - & +++\end{array}$

nt $=$ not tested.

Table 3. Precipitin reactions showing the reciprocal absorptions of type specific antibodies from type sera prepared from group $D$ strain 748 and group $N$ strain 736

\begin{tabular}{|c|c|c|c|c|c|c|c|c|c|}
\hline \multirow[t]{2}{*}{ ou } & & & & & \multicolumn{5}{|c|}{ Type specific serum 736} \\
\hline & \multicolumn{4}{|c|}{ Type specific serum $\mathbf{7 4 8}$} & & \multicolumn{4}{|c|}{ Absorbed with } \\
\hline & & & sorb & d with & & & & & M3 \\
\hline $\begin{array}{c}\mathrm{HCl} \text { extract } \\
\text { prepared from strain }\end{array}$ & $\begin{array}{c}\text { Un- } \\
\text { absorbed }\end{array}$ & & 736 & & $\begin{array}{c}\text { Un- } \\
\text { absorbed }\end{array}$ & $\mathbf{7 4 8}$ & 736 & M3 & \\
\hline group D & +++ & - & - & +++ & ++ & - & - & ++ & - \\
\hline $\begin{array}{l}\text { 36, group } \mathrm{N} \\
\text { trep. lactis } \mathrm{M} 3 \text {, group } \mathrm{N}\end{array}$ & $\begin{array}{c}++ \\
-\end{array}$ & - & - & $\begin{array}{c}++ \\
-\end{array}$ & $\begin{array}{c}++ \\
++\end{array}$ & $\begin{array}{l}t+ \\
t+\end{array}$ & - & $+t+$ & + \\
\hline
\end{tabular}

736 was found to possess a type antigen similar to that of group $\mathrm{N}$ Strep. lactis M3 in addition to the $\mathbf{7 4 8}$ antigen. Absorption with M3, together with $\mathbf{7 4 8}$ cells, still failed to remove all antibodies in the 736 type serum, and it appeared that further residual antibodies were present which could not be identified. Exhaustive absorptions with both M3 and 748 cells, using 6, 24 or $48 \mathrm{hr}$. cultures for absorption still failed to remove the antibodies from the serum. 
The major antigen appeared to be that shared by 748. Thus strain 736 contained one type antigen similar to that characterizing the group D streptococcus 748 , another similar to that of the group $\mathrm{N}$ streptococcus Strep. lactis M3, and a third unidentified type antigen.

$\mathrm{HCl}$ extracts of several other group D strains were also tested against these two type sera and one of them, 2766/1, gave strong precipitin reactions. One-sided absorption of both 748 and 736 type specific sera showed that this streptococcus possessed the 748 antigen, but not the $\mathrm{M} 3$ antigen. $\mathrm{HCl}$ extracts of the serological types described by Sharpe \& Shattock (1952) gave no precipitin reactions with type sera 748 or 736 .

\section{Physiological characters of strains of streptococci having the same type antigen}

The physiological reactions of the three strains of streptococci sharing the 748 antigen are given in Table 4 . The two group D strains are classified as Strep. faecalis or on the basis of their sensitivity to potassium tellurite and

Table 4. Physiological characters of strains of group $D$ and group $N$ streptococci having the same type antigen

\begin{tabular}{|c|c|c|c|}
\hline & \multicolumn{3}{|c|}{ Strain } \\
\hline & \multicolumn{2}{|c|}{ Group D } & \multirow{2}{*}{$\underset{\mathbf{7 3 6}}{\text { Group }} \mathbf{N}$} \\
\hline & S748 & $2766 / 1$ & \\
\hline Litmus milk (24 hr.) & rAC & $\mathbf{A C}$ & $\mathbf{R A}$ \\
\hline Mannitol & $\mathbf{A}$ & $\mathbf{A}$ & $\mathbf{A}$ \\
\hline Sucrose & - & - & - \\
\hline Raffinose & - & - & - \\
\hline Arabinose & A & $\mathbf{A}$ & - \\
\hline Sorbitol & - & - & - \\
\hline Maltose & $\mathbf{A}$ & A & $\mathbf{A}$ \\
\hline Dextrin & - & nt & $\mathbf{A}$ \\
\hline Trehalose & A & A & $\mathbf{A}$ \\
\hline Growth at $40^{\circ}$ & nt & nt & + \\
\hline Growth at $45^{\circ}$ & + & + & - \\
\hline Growth at $\mathrm{pH} 8 \cdot 6$ & + & + & - \\
\hline Survival at $60^{\circ}$ for $30 \mathrm{~min}$. & + & + & - \\
\hline Arginine hydrolysis & + & + & + \\
\hline Haemolysis & Greening & $\alpha$ & Greening \\
\hline Resistance to tellurite & - & - & - \\
\hline Gelatin liquefaction & - & - & - \\
\hline
\end{tabular}

fermentation of arabinose as, Strep. faecium (Skadhauge, 1950; Seelemann \& Carstens, $1951 a$; Sharpe \& Shattock, 1952). Strain 736, previously described by Seelemann as Strep. cremoris would seem by the fermentation of maltose, the hydrolysis of arginine and ability to grow at $40^{\circ}$ to be more closely allied to Strep. lactis, as Briggs \& Newland (1952) also point out. The group $\mathbf{N}$ Strep. lactis $\mathbf{M} 3$ has already been fully described in the literature (Shattock \& Mattick, 1943; Swartling, 1951). 


\section{Antigenic variations of group $N$ streptococcus strain 736}

To investigate further the antigenic structure of strain 736 , an $18 \mathrm{hr}$. glucose Lemco broth culture was plated on yeast dextrose agar and sixteen colonies picked off. $\mathrm{HCl}$ extracts of the growths from these were tested against type serum 736 unabsorbed, absorbed with Strep. lactis M3, or absorbed with strain 748 . It was found that although there was no colonial differentiation, two variants of different antigenic make-up were present: one, 'A', having all type antigens previously described for strain 736, and the other, 'B', having only'the Strep. lactis M3 type antigen. Absorptions of serum 736 were carried out with these two variants, and the results of several such experiments summarized in Table 5. Repeated platings of 736 cultures

Table 5. Antigenic relationships of serological variants of group $N$ strain 736 shown by cross absorption tests

\begin{tabular}{|c|c|c|c|c|c|c|c|c|c|}
\hline \multirow[b]{2}{*}{$\begin{array}{c}\mathrm{HCl} \text { extract } \\
\text { of strain }\end{array}$} & \multirow[b]{2}{*}{$\begin{array}{c}\text { Un- } \\
\text { absorbed }\end{array}$} & \multicolumn{6}{|c|}{ Type specific serum 736 absorbed with } & \multirow{2}{*}{$\begin{array}{c}\text { Type } \\
\text { specific } \\
\text { serum } \\
\mathbf{7 4 8} \text { un- } \\
\text { absorbed }\end{array}$} & \multirow{2}{*}{$\begin{array}{c}\text { Group } \mathbf{N} \\
\text { serum } \\
\text { lactis } \\
\text { OJ }\end{array}$} \\
\hline & & $736736 \mathrm{~A}$ & $736 \mathrm{~B}$ & $\begin{array}{c}736 B \\
\text { and } \\
748\end{array}$ & M3 & $\begin{array}{l}\text { M3 } \\
\text { and } \\
748\end{array}$ & 748 & & \\
\hline 736, group $\mathbf{N}$ & $++t$ & - & +++ & + & +++ & + & $+t$ & ++ & + \\
\hline $736 \mathrm{~A}$ (15 strains) & +++ & - & $+t+$ & + & $++t$ & + & ++ & ++ & + \\
\hline 736 B (27 strains) & $+t$ & - & - & - & - & - & + & - & + \\
\hline M 3, group $\mathbf{N}$ & ++ & - & - & - & - & - & $t+$ & - & + \\
\hline 748 , group D & $+t$ & - & $+t$ & - & ++ & - & - & ++ & - \\
\hline
\end{tabular}

always showed the presence of the two antigenic forms and in all cases the same antigenic patterns were observed. Absorption of type serum 736 with the undifferentiated homologous organism removed all antibodies in the serum, and so did absorption with 736 ' $\mathrm{A}$ '. Absorption with 736 ' $\mathrm{B}$ ' or with Strep. lactis $\mathrm{M} 3$ cells removed both the 736 ' $\mathrm{B}$ ' and Strep. lactis M3 antibodies. Further absorption of the serum previously absorbed with Strep. lactis M3 or 736 ' $B$ ' cells removed the 748 type antibodies still leaving antibodies which reacted with extracts of 736 and 736 ' $A$ '. As 736 ' $A$ ' cells removed all type antibodies they must have possessed all the 736 type antigens. Extracts of 736 ' $\mathrm{B}$ ' reacted exactly like Strep. lactis $\mathbf{M 3}$ in absorption tests and possessed only this type antigen. 736 has undergone variation, with the formation of a variant containing only one of the type antigens. All strains of 736 ' $A$ ' and ' $B$ ' reacted with specific group $\mathbf{N}$ serum.

Although two variants of strain 736 could be differentiated serologically, culturally and morphologically the differences were few. Colony forms on yeast glucose agar and on horse blood agar were indistinguishable even after ageing at room temperature or after prolonged incubation at $30^{\circ}$, being smooth in each case; the microscopic appearance was the same (short chains of Gram-positive cocci) except that the ' $B$ ' form tended to clump more than the ' $A$ '. No capsules could be demonstrated in either variant. Fermentation of maltose and dextrin, growth at $40^{\circ}$ and reactions in litmus milk were the same. The two forms were usually differentiated by their growth in glucose 
Lemco broth, 'A' appearing as a diffuse smooth growth throughout the medium and ' $B$ ' as a rough granular deposit. On suspending washed cells in $0.85 \%$ saline, ' $A$ ' cultures usually remained smoothly in suspension whilst ' $B$ ' cultures spontaneously agglutinated. However, a few of the ' $A$ ' cultures were also spontaneously agglutinated.

On subculturing four cultures of each variant in glucose Lemco broth daily for 10 days, the appearance in broth, serological reactions and physiological reactions remained unchanged. On replating an ' $A$ ' and $a$ ' $B$ ' strain and picking eight colonies of each, the cultural and serological characteristics of all colonies of each variant were those of the parent strain. There was no further dissociation or reversion. Freeze-drying of an ' $A$ ' and ' $B$ ' strain also produced no change in antigenic or physiological properties. Both variants appeared to be stable under the conditions described, and no further attempts were made to determine conditions which might cause dissociation.

\section{DISCUSSION}

Strains 748 and 736 each have a type antigen stimulating the production of antibodies which react with extracts of both organisms. Strain 736 is able to remove all type antibodies from $\mathbf{7 4 8}$ antiserum by absorption, and strain $\mathbf{7 4 8}$ removes a large amount of the antibodies from antiserum 736. These type antigens are then very similar if not identical. In view of the antibodies remaining in 736 serum after absorption with Strep. lactis M3 and with 748 cells, it may be that strain $\mathbf{7 3 6}$ possesses a more complex antigen than strain 748 and that, whilst the 736 antigen can completely absorb the antibodies from $\mathbf{7 4 8}$ type serum, the $\mathbf{7 4 8}$ antigen can only partially absorb the similar but more complex antibodies from 736 type serum. Alternatively, the residual antibody may represent still another type antigen.

It is not known whether the type antigens of strains 748 and 736 are carbohydrate or protein; they are not inactivated by pepsin or trypsin.

Other group $\mathbf{N}$ streptococci may have the same intricate antigenic pattern; only by chance was strain 736 studied in such detail as to reveal its complexity. The serological reactions of the group D strain 748 are simple by comparison, revealing a single type and a group antigen. No tests were made for nonspecific $\mathbf{P}$ substance.

Dawson, Hobby \& Olmstead (1938) have described antigenic variation in haemolytic streptococci. These authors found that alterations in cultural and morphological characters usually accompanied such changes. In the group $\mathbf{N}$ streptococcus described here no such correlation was observed.

The author expresses her thanks to Dr A. T. R. Mattick for many valuable suggestions and for his active interest in this work; to Prof. Seelemann for cultures and sera and for bringing these organisms to the author's attention; and to Mr L. G. Newland for technical assistance. 


\section{REFERENCES}

Abd-el-Malek, Y. \& Gibson, T. (1948). Studies in the bacteriology of milk. I. The streptococci of milk. J. Dairy Res. 15, 233.

BLrss, E. A. (1937). Studies upon minute haemolytic streptococci. III. Serological differentiation. J. Bact. 33, 625.

Briggs, C. A. E. \& Newland, L. G. M. (1952). The serological classification of Streptococcus cremoris. J. Dairy Res. 19, 160.

Dawson, M. H., HobBy, G. L. \& Olmstead, M. (1938). Variation in the haemolytic streptococci. J. infect. Dis. 62, 138.

Fuller, A. T. (1938). The formamide method for the extraction of polysaccharide from haemolytic streptococci. Brit. J. exp. Path. 19, 130.

LANCEFIELD, R. C. (1933). A serological differentiation of human and other groups of haemolytic streptococci. J. exp. Med. 57, 571.

MaXted, W. R. (1949). Occurrence of the M substance of type 28 group A in streptococci of Lancefield groups B, C and G. J. gen. Microbiol. 3, 1 .

Seflemann, M. \& Carstens, O. (1951 a). Die serologische Zugehörigheit des Sc. bovis und sog. atypischer Enterokokken zur Gruppe D. Kieler Milchre. Forsch. Ber. 3, 431.

Seelemann, M. \& Carstens, O. (1951b). Zur Biologie des Sc. lactis und Sc. cremoris (Gruppe L). Milchwissenschaft, 6, 231.

Sharpe, M. E. \& Shatrock, P. M. F. (1952). The serological typing of group D streptococci associated with outbreaks of neonatal diarrhoea. J. gen. Microbiol. 6, 150 .

Shatrock, P. M. F. (1949). The streptococci of group D; the serological grouping of Streptococcus bovis and observations on serologically refractory group D strains. J. gen. Microbiol. 3, 80.

Shattock, P. M. F. \& Hirsch, A. (1947). A liquid medium buffered at pH 9.6 for the differentiation of Streptococcus faecalis from Streptococcus lactis. J. Path. Bact. $59,495$.

Shatrock, P. M. F. \& Mattick, A. T. R. (1943). The serological grouping of Streptococcus lactis (group N) and its relationship to Streptococcus faecalis. J. Hyg., Camb. 43, 173.

Skadhauge, K. (1950). Studies on Enterococci. Copenhagen: Einer Munksgaard.

Swartling, P. (1951). Biochemical and serological properties of some citric acid fermenting streptococci from milk and dairy products. J. Dairy Res. 18, 256.

(Received 7 March 1952) 